\author{
Virginia L. Russell, FASLA
}

Virginia L. Russell, FASLA, Associate Professor of Architecture at the University of Cincinnati, holds a Bachelor of Science degree in Landscape Architecture from the University of Kentucky and a Master of Landscape Architecture degree from Ohio State University. Her research interests include Jens Jensen and The Clearing, experiential education and the Danish Folk School, the design of retreat centers, ecotourism, and the history of the ASLA. She has served in numerous positions for the ASLA, including national Vice President of Membership (1996-1998), and she is currently the national chair of the ASLA Archives Committee.

\begin{abstract}
The correspondence of Jens Jensen (1860-1951) and Frank Lloyd Wright (1867-1959) reveals an important relationship in the history of landscape architecture and architecture. The collected letters, dated from 1912 to 1943, reflect a passionate difference of opinion regarding design, education and pedagogy, practice, lifestyle, moral values, and despite the contradictions, a mutual regard that was sustained by their animated conversation. This paper selects those letters of Jensen, Wright, and other players in their drama that illuminate the history of two unusual schools of design: Jensen's Clearing in Door County, Wisconsin and Wright's Taliesin Fellowship in Spring Green, Wisconsin and Scottsdale, Arizona. The reader may wonder, which Master called the other "Prima Donna?"
\end{abstract}

$\mathrm{T}$ he legacies of Frank Lloyd Wright and Jens Jensen include more than their contributions to the philosophy of design described as the Prairie Style, born in the Midwest. Both men, disappointed in the results of higher education and wanting to teach on their own terms, created their own schools in Wisconsin: Wright's Taliesin Fellowship near Spring Green founded in 1932, and Jensen's Clearing in Ellison Bay begun in 1935. Their correspondence from 1912 to 1943, after Wright had left Chicago and they no longer met frequently around town, is an important record which documents the evolution of both schools. In these letters they find in each other an uncommon support for the idea of a new, distinctly American school for the training of architects and landscape architects.

\section{Background of the Research}

This author's inquiry began with a week at The Clearing in 1989, as the realization of a goal set in graduate school and an unfulfilling reference to the place in her thesis about the design of retreat centers. Reading what could be found about Jensen was the warp of a tapestry woven with colorful characters like Wright, and for want of published material about Jensen, the author turned to his correspondence to find the pattern of his school's development. Knowing only vaguely that there was a connection to Wright and Taliesin, the author's search led to Wright's correspondence for a more personal view than what was told in the many books about the Taliesin Fellowship. Wright's letters are easy to find; most are available on carefully indexed and cross-referenced microfiche at the archives of the Frank Lloyd Wright Foundation at Taliesin West in Arizona, under the meticulous care of a dedicated staff and Bruce Brooks Pfeiffer, or in various archives across the country. Jensen's letters, including those to and from Wright, are more difficult to collect. Morton Arboretum and The Clearing have a more or less redundant collection of Jensen's correspondence, and because there is no Jensen equivalent of the Frank Lloyd Wright Foundation, it is difficult for owners of Jensen archival material, including Jensen's descendants, to know the proper repository for their private collections.

Another obstacle presented to the Jensen scholar is the result of a 1937 fire in The Clearing's Lodge, which destroyed Jensen's art collection, his drawings, and his documents. Neither the Morton Arboretum nor The Clearing's collections include the correspondence of Wright and Jensen, although they do include extensive correspondence with people from the time before and after the Lodge fire. The primary source of Jensen correspondence is Morton Arboretum. The remainder is found in the collections of those to whom he wrote, such as the Library of Congress collection of the Wisconsin legislator Phillip 
LaFollette, in the Franz Aust collection of the Wisconsin State Historical Society, and in other scattered sites.

Once the Jensen correspondence has been found, perhaps the most difficult obstacle to overcome is the challenge of Jensen's handwriting (Figure 1). Much of his correspondence was typed by his secretary and assistant at The Clearing, Mertha Fulkerson (Figure 2). There must have been occasions when Jensen hesitated to interrupt her weaving or other duties so he took it upon himself to hand write his letters, and the majority of the letters from Jensen to Wright are handwritten. ${ }^{1}$ This author has observed that much of Jensen's correspondence appears on stationery printed with The Clearing's logo, and this includes the earlier letters from his Ravinia studio by the Eime name. However, many of the Retters appear on stationery with 獭e same long thin pine tree drawing "Wove the name "West Blow," which ติay have been the earliest name of the Ellison Bay Clearing, perhaps then it was still the family vacation property.

A story that appeared in a 1943 edition of The Milwaukee Journal substantiates the difficulties of translatîng Jensen's handwritten script. The Seporter interviewing Jensen at The Clearing asked him to describe क् Ф્.ld a story on himself to illustrate 苦e challenges of providing hospitaly to the many unexpected visitors ⿷匚⿱ Fुne occasion, there was nothing in Aitchen to serve for dessert, so Jensen scribbled a note requesting Danish coffeecake and sent it to the bakery in the nearby village. When Jensen opened the bakery box to serve the dessert, he found caviar. ${ }^{2}$ This author can certainly sympathize with the baker's translation of Jensen's handwriting and his efforts to appease this notoriously intemperate man by scrambling to find caviar in the wilds of Door County.

The letters are presented here in an order that builds the understanding of their relationship, the early days of struggle at both schools, their pedagogy, and the end of their friendship. The letters have not been corrected for grammar or spelling; a few letters have been edited for relevance or length.

\section{Background of the Masters}

The story of Jensen and

Wright's professional collaboration is fairly well known, documented in Leonard Eaton's book Landscape
Artist in America (1964), and more recently in Bob Grese's book Jens Jensen: Maker of Natural Parks and Gardens (1992). In 1893, Wright left his apprenticeship with Adler and Sullivan and began his own practice by cultivating the moderately wealthy suburban clientele of Chicago. Meanwhile, Jensen's stormy dealings with

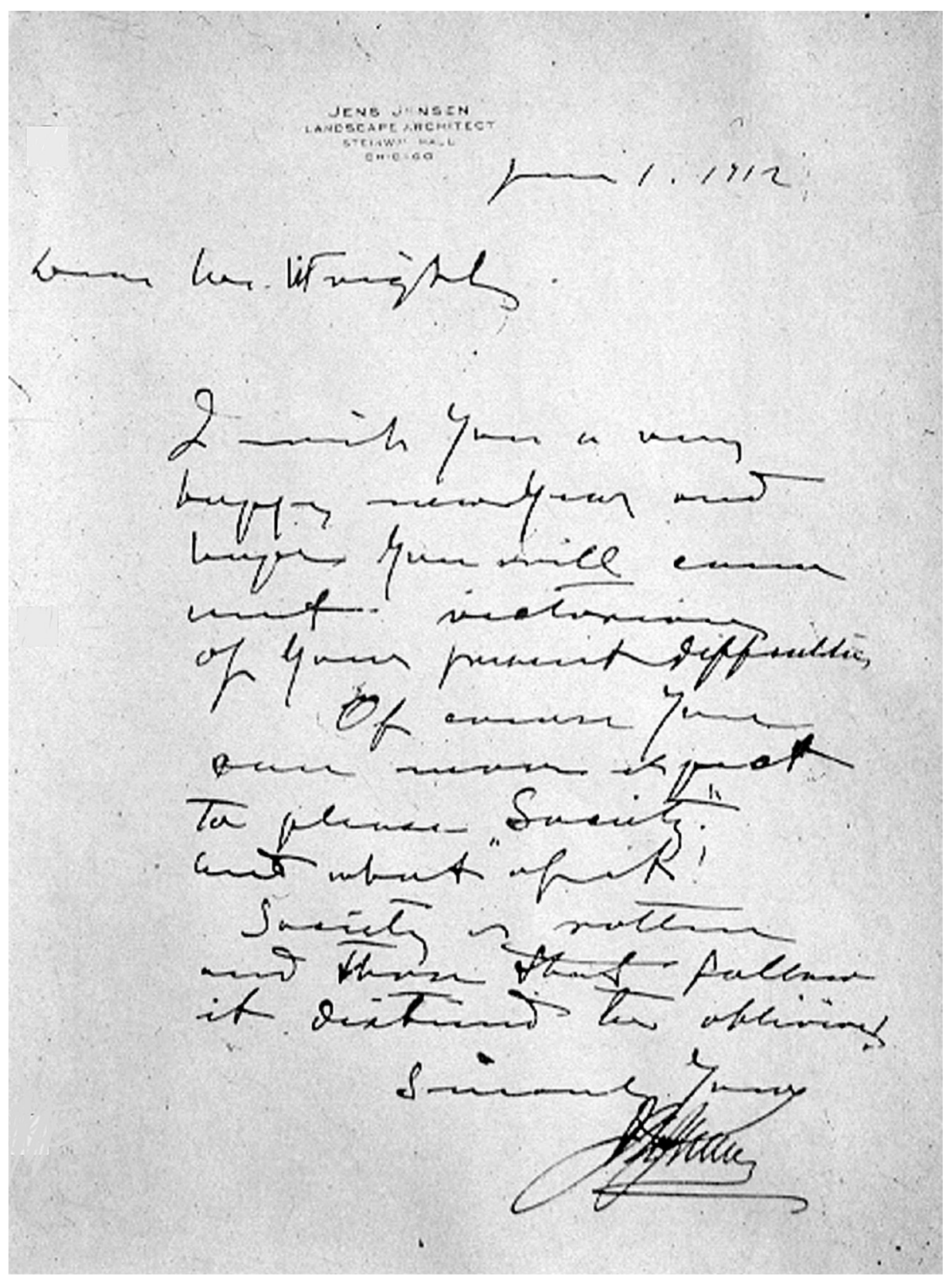

Figure 1. A New Year's greeting from Jensen to Wright, dated January 1, 1912, which reads: "I wish you a very happy new year and hope you will come out victorious of your present difficulties. Of course you can never expect to please "Society" but what of it! Society is rotten and those that follows it destined to oblivion!" Courtesy of the Frank Lloyd Wright Foundation. 
Chicago's leading citizens, who resisted his ideas for natural parks and his battles with political graft, were ironically securing for him an impressive list of estate design projects for the industrialists Henry Babson, Henry
Ford, J. Ogden Armour, and others. Jensen's attempts to persuade his clients to employ the architects of the Prairie Style, including Wright, were often fruitless (Eaton 1964, p. 210). For a time Jensen and Wright both

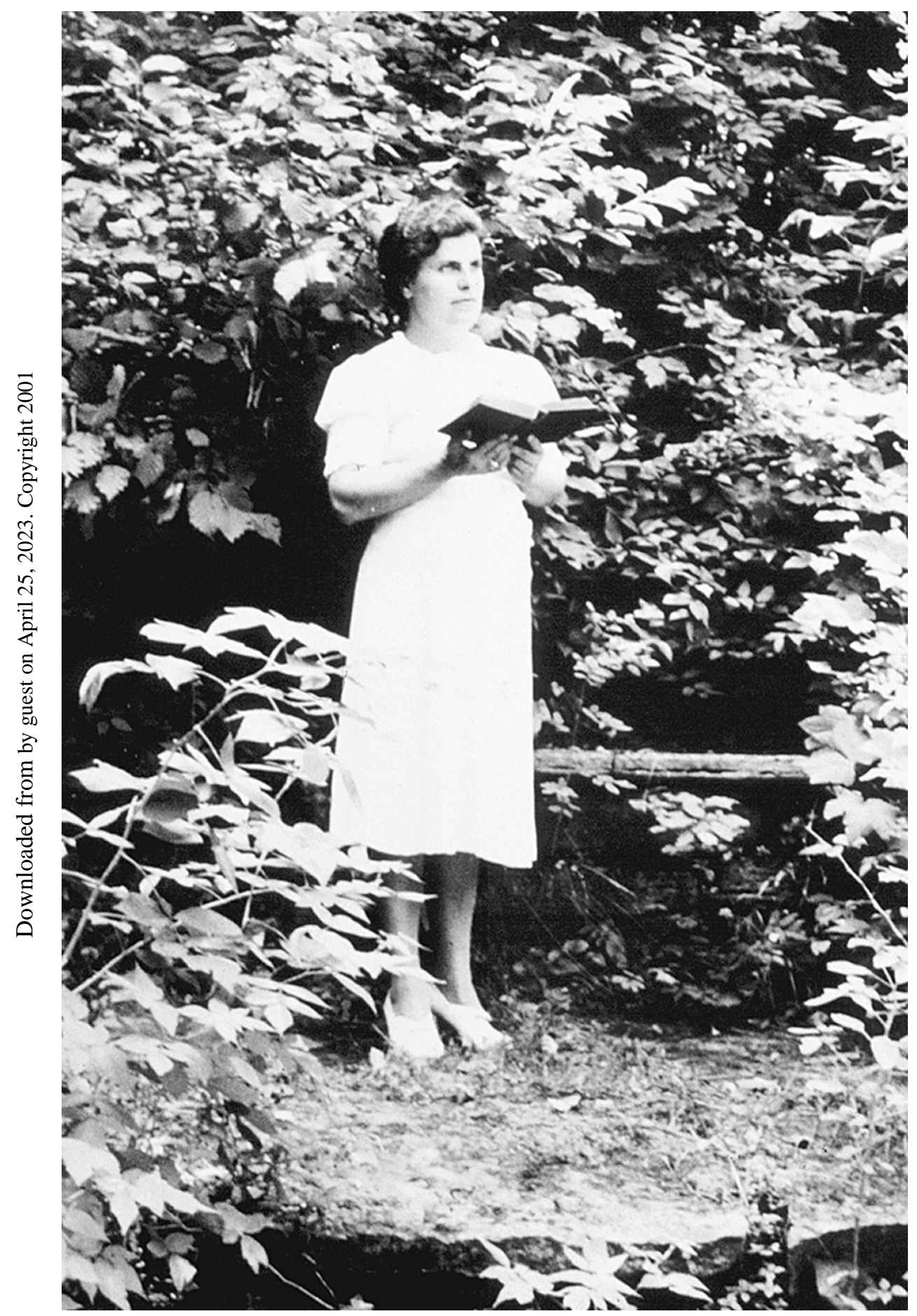

Figure 2. Mertha Fulkerson, (n.d.) who became Jensen's secretary at the age of nineteen and his successor at The Clearing in 1951. Courtesy of The Clearing. had offices in Steinway Hall (Grese 1992, p. 44), Wright was a frequent visitor at the Ravinia studio $;{ }^{3}$ they were both members of the Cliff Dwellers club and other social and literary groups, and frequent visitors at Jane Addams' Hull House. They did collaborate, however moodily, on five residential projects from 1908 to 1936 (Figure 3). ${ }^{4}$ The earliest letters they exchange are brief invitations to attend discussions and lectures, and after 1910, when Wright had moved to Spring Green, the letters are longer, replacing the frequent contact they had when they ran in the same social and professional circles of Chicago.

\section{Friendship and Cynicism}

In a 1930 letter to Jensen, Wright described his suffering at the hands of his architectural colleagues for their "malicious propaganda" about him, and offered to Jensen some speculation about why they had not worked together more often:

However, even friends (like yourself for instance) seldom give me a hand unless dragged in by the beard or back-hair and intimidated? During 27 years for instance never has any work on your account come to me or any on my account gone to you, although I have had little or none to give these past ten years having been in deep trouble. It would be quite natural that you should want to work with me, whenever you could? yes? But is it that a Star is seldom willing to share with a Star. The Star will seek lesser men to accomplish his purpose, as a matter, he mistakenly thinks, of self-preservation. (Wright 1930)

Jensen's response to this letter begins with a modest objection to being described as a "Star," and continues:

I have no such aspiration, and as for you, you ought to be exceedingly happy to have been gifted in certain ways that it has been made possible for you to assume leadership in certain phases of lifes [sic] work. In that alone lies all the glory of life here. There can be no other. Mere material glory gives no genuine pleasure.

You have no cause for any bitterness towards your fellow man. 
You have succeeded beyond most mortal kinds, if real accomplishments is [sic] success, as it is measured by human minds. I am not envious. Great accomplishments carry with them great responsibilities. Those you cannot escape. I have no quarrel with you nor any man as long as they do not infringe upon my ideals of life, travel their own way as they see and understand life, like the stars in their own sphere without interference with the others, yet all joining in a harmonious whole, lighting up the heavens for the joy and inspiration of all of us . . . But ideal life does not exist as it should. We are no gods, but just humans, created in the reflection of the Great Master, but we do know what is right and what is wrong and may choose either path. They that are less successful will steal from those that are more ... I have resigned myself to this, for I too have taken soundings, and I too know what I have accomplished and that knowing gives me joy, peace and happiness . . . I can forget those that steals my work and calls it their own.

I wish to be remembered to your good wife, and to yourself a parting word-Look over your snow covered hills, across the valley of the purple horizon, over this noble creation that is not of your making, and be happy that you are able to enjoy and appreciate it in so great a measure. (Jensen 1930a)

This exchange demonstrates a trpical pattern in the correspon\&ence of Jensen and Wright. Wright Gils against his circumstances and Ensen calms him with stern and modest admonitions. When Wright proclaims his superior but misunderstood abilities, Jensen brings him down with homilies and reminders to count his blessings. Perhaps this reveals Jensen's absorption of the basic tenets of the Danish Folk School, which was his pedagogical model for The Clearing, and its guiding principle of jantelov, which translates as "relentless leveling." David W. Leslie describes this leveling as an important aspect of the Danish personality:

[Jantelov] ... provides an informal but powerful check on ambition or ego display in Danish society. Selfpromotion and high achievement are likely to meet open ridicule and disapproval. (Leslie 1995)

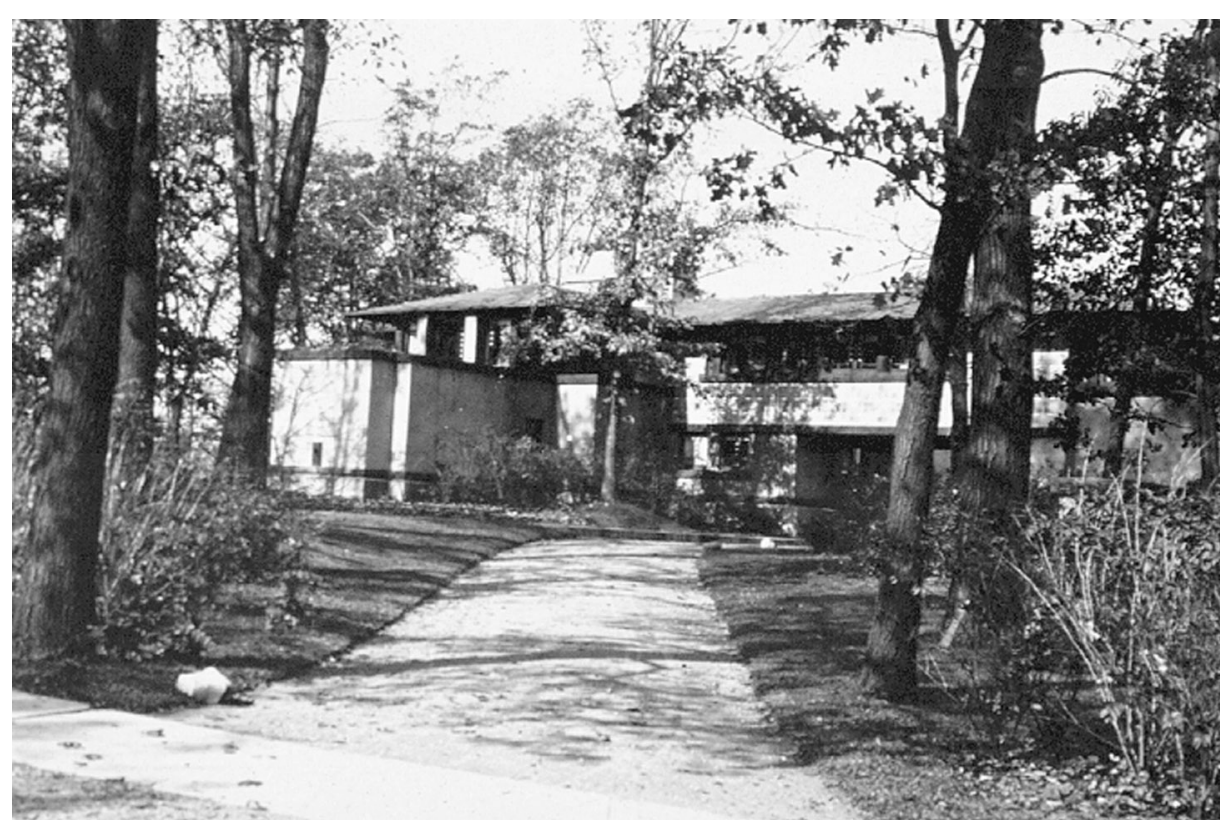

Figure 3.The Avery Coonley House, one of the Jensen/Wright collaborations. Courtesy of Morton Arboretum.

In an earlier letter to Jensen, Wright mentions their dialogue about the character and creative attributes of Man, and his intentions for his own school:

Now I believe the creative instinct in Man is that quality or faculty in him of getting himself reborn and born again-of getting himself born into everything that he does, everything that he really works with ... Now how to get it back-this quality of Man-back again to men ... Our first concern about that should be the first thought of every thinking man in our country today

And that Jens, is why I am interested in this proposed school. I should like to be one to initiate steps that would put a little experimental station at work where this thing might be wooed and won, if only to a small extent. I know it cannot be taught. (Wright 1928)

Both men were cynical about the state of higher education in America, perhaps because Wright left the university environment with- out a degree and yet made a way for himself, and Jensen's education in the Danish Folk School taught him to value experience more highly than books and lectures, but that did not stop either man from accepting honorary doctorates or soliciting universities for money or resources to support their schools. In a letter to Alice Drought, with whom Jensen had an extensive correspondence about the site for his school, Jensen states:

... My feeling on this school matter is that we have to fight the artificial civilization of our cities to be able to create a sound and honest cultural background. A school like that is not for Landscape Architects. Where they evidently would be the minority. It would be more for Poets, Philosophers, Painters, Sculptors, Musicians and especially Composers, Dramatists, and perhaps Architects and Landscape Architects. When I meet a professional man, architect, I always feel that he is of a narrow type, and therefore unable to grasp the depth and real meaning of such an educational Institution. (Jensen 1930b)

Wright was cynical not only about the product of a professional 
degree program, but the motivations of the students and parents. $\mathrm{He}$ stated:

Most parents have children ... So they have to be sent somewhere. And of course these schools and colleges are more or less creches, different stages of creches to which we send the boys and girls because we can't do anything else with them. It's too much trouble ... So education is more or less a refuge for shall we say the incompetent? Anyway, the colleges are doing a great work to relieve parents of their responsibilities. (Pfeiffer 1987)

\section{Domestic Catalysts}

At this juncture, the author suggests that the domestic situations of Wright and Jensen were the catalysts for the creation of the Taliesin Fellowship and The Clearing. Wright found himself in a sort of chosen exile, where circumstances would lead to the decision to stay put and rebuild his life. Similarly, the death of his wife gave Jensen the grievous freedom to cast off the city and rebuild his life around a dream.

\section{Taliesin Fellowship. Although} both Jensen and Wright revered nature in their work, they were philosophically opposed on the domestic front. While Jensen and his beloved Anne Marie were thriving in Ravinia, Wright was becoming notorious for his affairs, one of which would eventually precipitate his desertion of his wife and six children in 1909 with Mamah Borthwick Cheney, the wife of a client in Chicago. After a trip to Europe, Wright and Mrs. Cheney took refuge in the remote Jones valley in Wisconsin where Wright was raised. Wright's exile with Mrs. Cheney brought him closer to realizing his dream of building a school for the allied arts. Twenty-four years earlier he had designed and built for his aunts the Hillside School, an unusual co-ed institution, on his family's farm. As the aunts aged, and the financial hardships of the early 1900s took their toll on the school's census, they urged Wright to ensure that it would continue as an educational facility (Pfeiffer 1982, p. 3). In 1911
Wright built his home there, and following the tradition of his family to use Welsh names, he christened his home "Taliesin," meaning "shining brow," after one of the knights of King Arthur's Round Table and a Druid poet (Meehan 1984, p.44).

There were hardships one after another: Mrs. Cheney was murdered and Taliesin was virtually destroyed by fire in 1914. But Wright stayed on, bringing in apprentices to continue his practice, rebuilding Taliesin and restoring Hillside School, and eventually remarrying, first Miriam Noel, and finally Olgivanna Hinzenburg (Figure 4). Despite another devastating fire in 1925, Wright's practice was surviving, with twenty-three apprentices working in the studio, the only major part of Taliesin to remain untouched by both fires. Wright found this ominous; he believed God had condemned his lifestyle by destroying his home, but endorsed his work by sparing his studio (Pfeiffer 1982, p. 3).

For Wright, marriage with Olgivanna brought a stability and cultural richness to Taliesin, and it was in this atmosphere that they decided to formalize their school. Wright's restoration of the Hillside School was intended for his own school, but his financial circumstances would not permit this, and Wright found himself in a desperate state. ${ }^{5}$ In 1927 , he approached a mutual client of his and Jensen's, Mrs. Avery Coonley, and asked her to buy the Hillside School. He asked Jensen to back him up in persuading her. He also asked Jensen if he might have any friends interested in buying his art, and if Jensen might advise him about how to proceed in this difficult time:

I have beautiful Object D'art that anyone who knows fine things of the sort would be proud to own. I do not want more for them than they are worth. With your help some of your people might be willing to buy them or take them as security for a loan of enough to make the ends of the economic situation meet, and be made happy themselves.

I have gone as far as I can, I fear in my little circle of loyal defenders of my faith.

Will you come into that circle and take an active part in my accounts and that means my architectural salvation at this moment?

If you will devote some of your time and energy to me, Jens, write me and let me know and we will get together and talk it all over and take stock of ways and means.

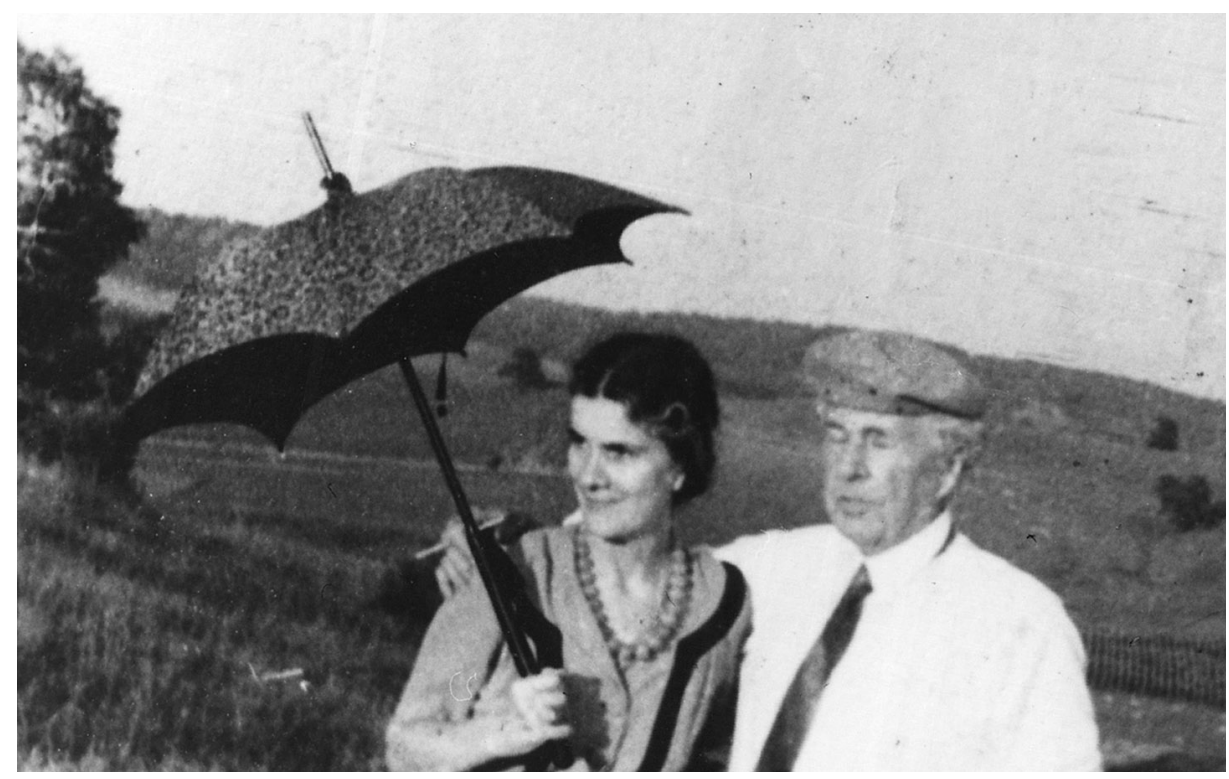

Figure 4. Frank Lloyd Wright and Olgivanna at Spring Green, 1930. Courtesy of the Frank Lloyd Wright Foundation. 
I, somehow, reach out to a conservation I feel in you, I have not built up in myself-in other words-I would avail myself of your strength in my weakness-now. (Wright 1927)

Jensen's reply includes a bracing cocktail of jantelov and homage, but no money:

Where in heavens did you get the thoughts from to write those words? It sounds like a bootlegging contractor or politician. You ought to be ashamed of yourself. What I do not understand is why those wonderful hills and your beautiful house have not made you more sensible.

When you say you are a stranger in your own land you are quite right. But the prophet has always been stoned by his own people. As I told you the visit to your house was an event in my life ... I know that the impressions carried with me-some from your interiors, some from your exteriors, of course not including the Chinese Gods-was that the American of tomorrow will want to live in that sort of a house. It is like the American but he does not know it...

I certainly would be glad to

help you, not with money as you state, because I have not got any and I never shall have any. I will always consider you as a friend and have never failed saying so in public when others stoned you. (Jensen 1927)

Wright continued to pursue the E్ Grong support in another mutual Eiend, Professor Franz Aust of the Êniversity of Wisconsin-Madison. Aust and Wright worked together on a proposal for the University of Wisconsin to support Wright's school. In December of 1929, Wright and Aust met with university faculty and administrators to present the proposal, which included letters of support from Jensen and others. In a subsequent letter to Aust, Wright makes his dissatisfaction with the meeting clear:

You will probably be unable to imagine my surprise and chagrin to find, the other day at our meeting; the school I had proposed and planned so far drifted from its orig- inal character and intent. Taking Frank Lloyd Wright out of the picture to substitute F.L.Wright and remove the original impulse to

"Door County" seems necessary, in your opinion, to the success of the revised idea?

I came forward with a definite establishment that was no experiment but an accomplished fact in the world of creation that would command united, distinguished, and effective support just because Frank Lloyd Wright had for thirty years or more fought for it single handed and given it a place in the estimation of a superior cultural world.

I asked for aid and comfort in carrying the inner thought or principle of that work and its details further along in behalf of the many young men and women who are writing continually to me to find out where those principles and ideals are at work so that they might share in that work.

To date there is but one such place in the United States and that is the little studio at Taliesin. If you imagine "Cranbrook" is even similar you must guess again. If you imagine Jens Jensen knows what that central idea distinctly is, as I know [sic] see, or would ascribe to it if he knew, you must guess once more...

This sounds as though I imagined myself to be the particular priest, exponent, or what-youwill, of the working principle in question, and the further into discussion I get with those who are supposed to know, or suppose they know, the more likely that assumption looks, even to myself.

... I reached out to an ubiquitous University, through you as a slender means of communication, to ask recognition and approval and help to make more useful in behalf of our state and country this work that has already changed the thought and remodeled the forms of the entire European modern world. Yes, why assume a modesty that is political or hypocritical?

Your own assumption that such effort should not be "dominated" (your low-down for "Inspired") by any single or central person and should not have the back-ground, even, of the Art of Architecture, that Art containing in itself as it does all the others, as the frame-work and true back-ground of civilization itself, is too much apiece with the ignorant-prejudice of the academies to deserve more than contempt. (Wright 1929)

The reference to "remove the original impulse to Door County" may come from the discussions among Jensen, Wright, and Aust about the proposed schools, and Aust had been taking his University of Wisconsin landscape architecture students to Door County to work with Jensen on what was then still his vacation property, but was under consideration as the site of Jensen's school. One could speculate that in the course of the discussion, someone, perhaps Aust, suggested that there should be such a school as a satellite of the University, and suggested that it could benefit from the inclusion of several prominent people, including Jens Jensen. But indeed, a Star is seldom willing to work with another Star.

An arrangement with the University would have been an expedient means to support Wright's school, but he was apparently determined to be the potentate regardless of who paid the bills. Wright issued the University an ultimatum that his offer would be withdrawn as of April 1, 1930, and in an immediate reply Aust made a conciliatory effort:

Every one agreed that it was a big idea. An idea that should be fostered, nurtured and grow at Wisconsin. Everyone recognized the highly inspirational value of your work, your studies and I would say your home as it is today. Everyone who has participated in our visits to Taliesin has felt and testified of that influence... The idea is a big one. It can't die! Here's wishing you every success. I'm "licked" but I'm with you $100 \%$ whether the door is left open or closed. (Aust 1929)

Wright continued to approach friends, relatives, banks, and grant funding sources. In 1932 the Taliesin Fellowship was announced, and in early 1933 a lengthy prospectus was 
mailed to all parts of the world. The concepts described within the brochure were immediately abandoned because Wright found them to be "too educational" (Pfeiffer 1982, p. 8), but the absence of a current brochure did not stop the flood of inquiries, and the Taliesin Fellowship enjoyed immediate success. Wright and the apprentices contributed a column called "At Taliesin" to several southern Wisconsin newspapers and this publicity, and the invitations to the public to attend the films shown in the Hillside Theatre, drew the curious to Taliesin in such numbers that Wright saw them as a source of income and began to charge fifty cents a person for admission to the grounds (Henning 1992, p. 18).

Three years earlier, Wright asked Jensen to critique an early draft of the school's first prospectus. In his reply, Jensen inflicts the principle of jantelov somewhat ruthlessly, and there is a hint that Wright had invited Jensen to be an instructor:

I can agree to most of what you say, but you are so prosaic in your delivery that I wonder how you can write poetry in stone, on book covers and tell stories about your life and the Imperial Hotel. Evidently you have two natures. Your analyses are that of a man analyzing dead and not living things. Do not try to analyze the philosophy of life. It needs no analyses and cannot beit is life. It is youth, it is growth, no more and no less. Words, mere words do not change this. It just gives so called learned men and women a chance to gossip about it, to write books-words and more words-lies and more lies. ... You will have to make some changes if I am to have anything to do with the school. The general principles are all right, but there are a lot of nasty rules and regulations and uniforms and labels; and why you want to submit intelligent minds, or whatever you call it, to the ordinary management demanded by the mediocre, I do not understand. (Jensen 1929)

The Clearing. The domestic catalyst that prompted Jensen to build his "School of the Soil" was the death of his wife, Anne Marie, in 1934 (Figure 5). Spirn asserts that Jensen ". . . was
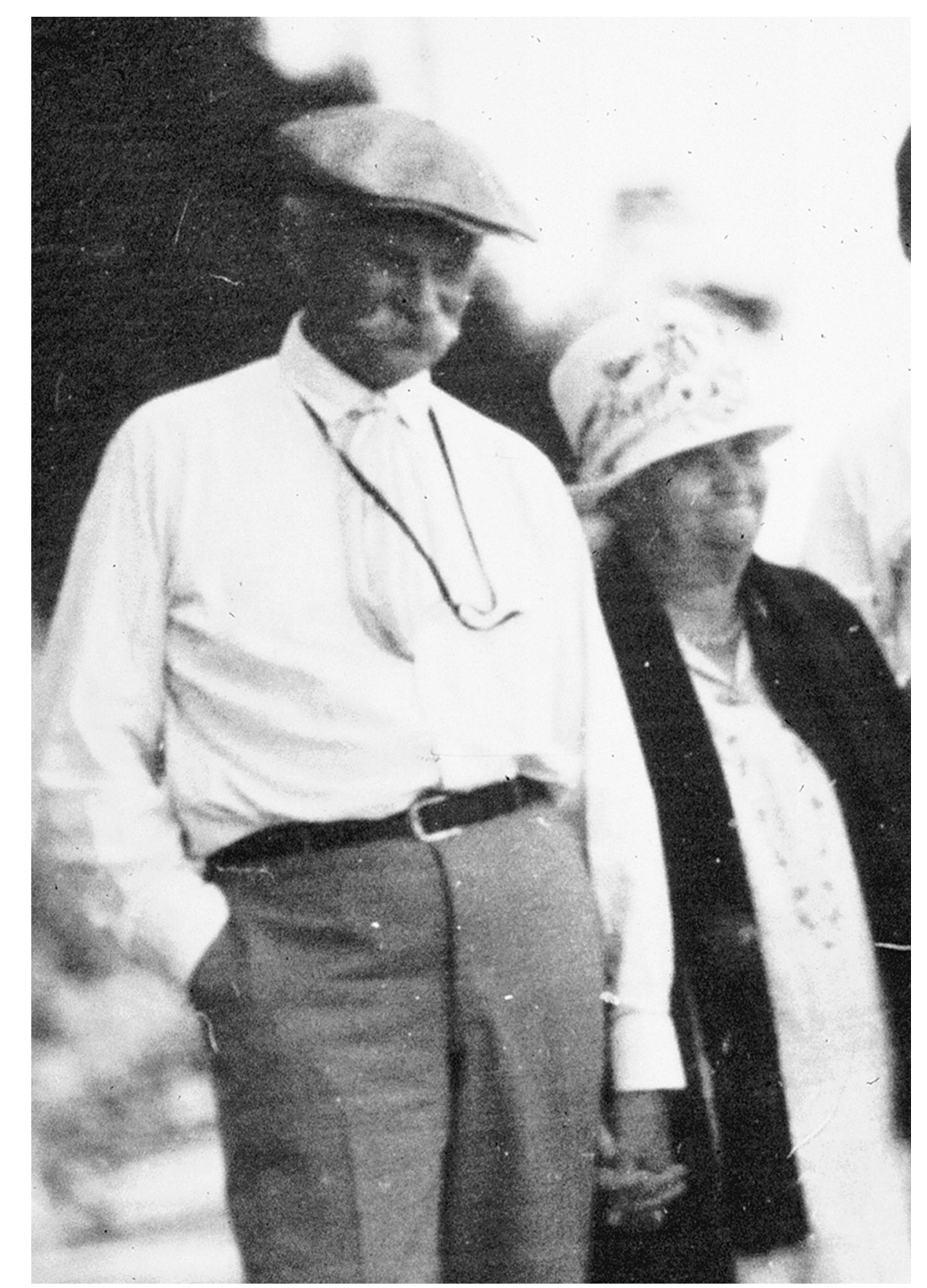

Figure 5. Mr. and Mrs. Jensen, ca. 1930. Courtesy of The Clearing.

inspired by Wright's example to found a school ..."6 and although by date of each school's opening, this statement is chronologically correct, Jensen was well ahead of Wright with the idea and his attempts to imple- ment it. For over twenty years Jensen had been making plans and scouting property for The Clearing, a place named for the clearing of the mind, like his Ravinia studio. Prior to his purchase of the Ellison Bay property in 1919 for family vacations, Jensen sent out apprentices from his Ravinia studio to find a site for his school, “. . a place where rural life bordered 
on the wilderness . . . an outpost facing the setting sun for there was the hope of tomorrow" (Fulkerson and Corson 1972, p. 13). Fulkerson was nineteen years old in 1924 when she interviewed with Jensen for a job as secretary at his Ravinia studio. She recalled that he spent about ten minutes telling her what her duties would be, and then a few hours passionately describing ideas for his school (Fulkerson 1970).

Jensen's trips into the Midwestern countryside to lead the Friends of Our Native Landscape ${ }^{7}$ resulted in several schemes to preserve the rural and wild landscapes, including a considerable amount of energy focused on the dunes of Lake Michigan. In the early 1900 s, a group of people in the Chicago area who enjoyed Saturday outings into the countryside eventually got themselves organized Im to the Prairie Club, electing their 局st president in 1911. Jensen was Teir director from 1911 to 1914 , किeir president in 1914, and is credit:ed with giving the club its name Đoeserich 1941, p. 7). In his associafiron with this group, he attempted Invice to develop two schools in the Giana dunes, one intended to be àn outdoor laboratory for Chicago Eีniversity, and the other intended to e a school for forestry, landscaping, ând market gardening. Eventually the activism of Jensen and the Prairie Ëlub would see this area designated ans the Indiana Dunes State Park, but He early efforts to have his own 蛋hool there never found the fund要g to begin.

The constant turbulence of Jensen's practice in Chicago and Anne Marie's death inspired his restorative December trip to California to visit family. While in the west, he visited the temporary camp of the Wrights in Arizona where the Broadacre City model was being built. ${ }^{8}$ In a few years, this area of Arizona would become the winter home of the Fellowship, called Taliesin West. This was not Jensen's only visit, and his participation in the Taliesin Fellowship was enthusiastically noted in their weekly newspaper column "At Taliesin." This entry describes one apprentice's impression of Jensen that December of 1934:
Despite the unceasing flow of energy that manifests itself in human lives there is one energy, that cosmic spark, that the Universal Spirit reserves for great men. Two such great men have just met at Taliesin-our master, Frank Lloyd Wright, and the poetic naturalist, Jens Jensen. With different words these two strong men sing a freedom song for the beauty of America. We apprentices are at Taliesin to build our master's song into our lives. Jens Jensen offered to our score a new theme to aid in the building. This Dane, with all the strength of his powerful vitality, is trying to help Americans be Americans by conserving their regional foliage and intelligently replanting where men have scarred the landscape ... His experiences are to the listener as fresh as ice crystals on pine boughs. (Henning 1992, p.94)

A column in March of 1935 indicates that Jensen had been to Arizona again, and gives an account of the affection and admiration of the Fellowship (Figure 6):

Jens Jensen, a true friend of the Fellowship, surprised us with his unexpected visit Tuesday night. We climbed a San Tan peak together and listened to his inspirational words. Jensen and the saguaro, their strength and character, the principle of their structure gave us cause to think, the desert breeze sweeping across our faces. He left us against our will Thursday morning and disappeared in the cottonwoods on his way to Los Angeles. The desert-each flower, each plant-will always bring him back to us. (Henning 1992, p. 118)

In Arizona and in Wisconsin, Jensen participated in the lively activities of the Taliesin Fellowship. He observed its function as a community, working and living and playing together, and despite the financial hurdles, they seemed to be enjoying the realization of a unique education, and this must have given him the belief (but not the idea) that his own school could thrive as well. Fulk- erson (1970) relates that if not for his wife's reluctance to live in Door County, and then her illness, Jensen would have given up his practice and moved to Ellison Bay to start his school much sooner. Upon his return from the west, Jensen burst into the Ravinia studio proclaiming, "When the snow goes and the frost is out of the ground I will be going north to build The Clearing. I have delayed far too long. The need for such an example is becoming more acute, and one of these days I shall be an old man." Mertha Fulkerson reminds us, "Mr. Jensen was then seventy five" (Fulkerson and Corson 1972, p. 14).

\section{Surviving Depression and War}

For years, Jensen had been "carrying his practice under his hat," and although he had a few projects going he would have to rely heavily on donations from wealthy clients to build his school because he had only a modest retirement annuity from the Chicago Parks system as a regular income (Eaton 1964, p. 211). He used this annuity to improve and winterize the vacation buildings already existing at The Clearing and had nothing to spare for the construction of facilities for a school. In the throes of the Depression, and then during the depravations of World War II, both Wright and Jensen solicited funds from their friends and clients for their schools. In Jensen's letters to Babson, Ford, and others, he makes it clear to them that it is their responsibility to support The Clearing for the sake of America's youth. In their replies, they commit to giving supplies or equipment, but state that no money would be given unless it could be tax-deductible (Stern 1938). ${ }^{9}$ As a result, Jensen incorporated The Clearing and formed a Board of Directors, then successfully pursued non-profit status for his school. After this, his wealthier clients gave him sums that must have seemed enormous at that time, from $\$ 500$ to $\$ 11,000$ (Fulkerson and Corson 1972, p. 27).

Following Jensen's example, Wright applied for non-profit status 


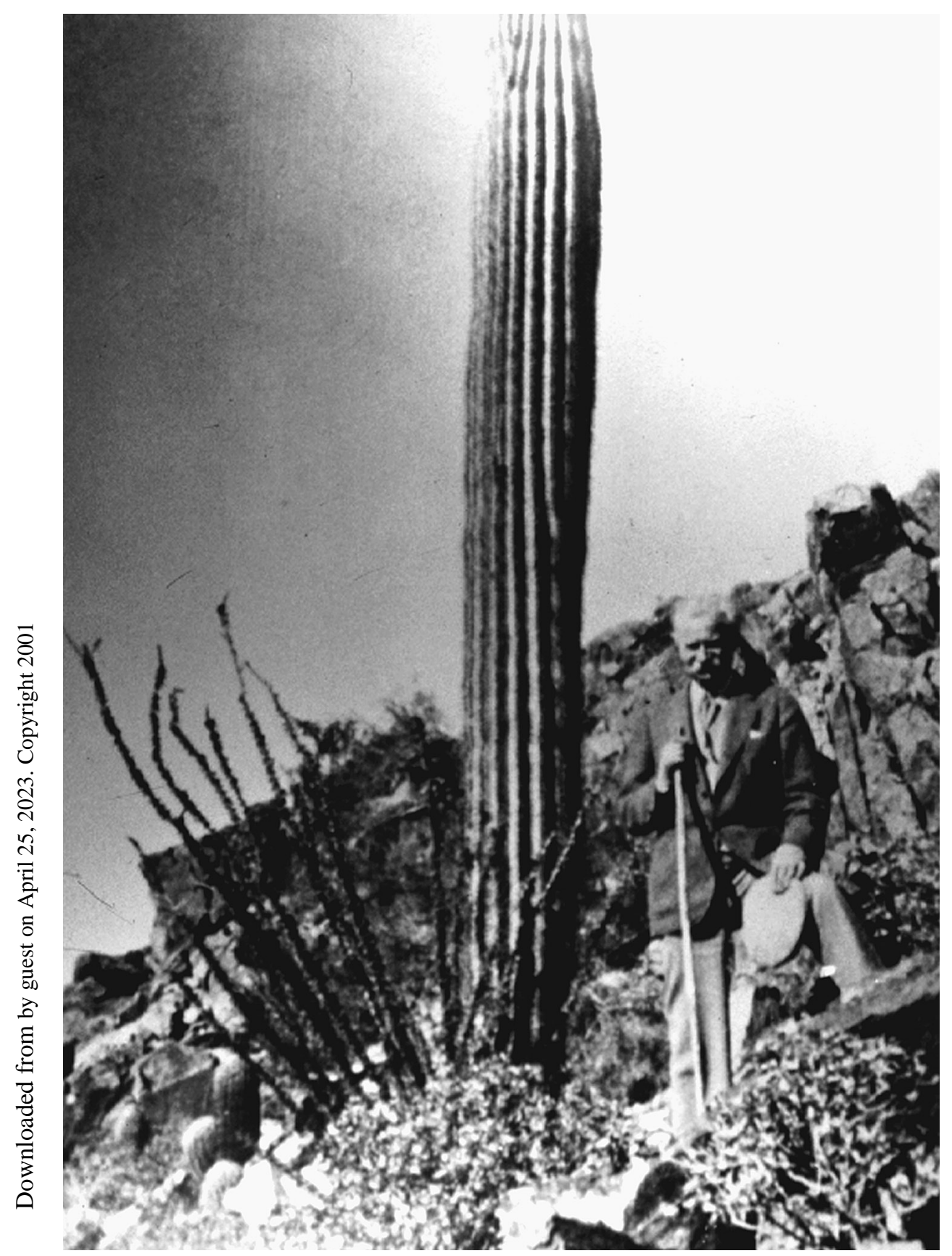

\section{Pedagogy}

Eventually Wright achieved another sort of formal recognition for Taliesin in the form of applying for accredited degree status as a School of Architecture. ${ }^{12}$ It is unlikely that Jensen ever entertained this idea for The Clearing. He preferred to reach for a broader student body, not necessarily intending to produce trained landscape architects, but rather seeking anyone from the city who wanted to learn about the native landscape. Although both Taliesin and The Clearing were conceived as communities of learning, a fundamental difference in teaching approaches existed. At Taliesin, there were "apprentices," and at The Clearing there were "students." All shared in the construction and chores of their schools, but the impression one gets is that manual labor at Taliesin kept the apprentices humble, whereas at The Clearing it was a method of learning intended to replace, not supplement the directives of a Master. This author does not intend to suggest that Wright's Taliesin was a sweatshop, for like Jensen, he had a great paternal affection for his apprentices. Both men were generous when neither could afford to be. They often waived tuition for students in need, and during World War II, students who arrived without their ration coupons were not turned away. Later, they welcomed veterans with or without the support of the GI Bill. ${ }^{13}$ According to Leonard K. Eaton:

Jensen's school was entirely lacking in the exploitative elements which were so apparent at Taliesin ... Both Wright and Jensen believed in the value of manual labor, but with Jensen its primary significance was the physical and spiritual contact which it provided with the earth ... Wright, in contrast, evidently believed in manual labor as a disciplinary measure. It helped to induce a proper humility in the student. (Eaton 1964, p. 218)

Further study may prove that Wright and Jensen founded schools primarily because of their dreams and ideals, but also because in their dire financial circumstances, through tuition the apprentices or students 
who arrived from all over the world to work for them would have to pay them, not vice versa. Gill describes Wright's motives:

The nerve-wracking difficulty of living beyond one's means had been eased for him by his simply and exquisitely having no more need of means; a small army of robust young folk would serve him night and day, paying him a considerable sum for the privilege of being in his presence whenever he felt inclined to let them enter it. He made no pretext of being a teacher; rather, he was an example, whose usefulness to them had but one undeniable defect: he was a genius and as such by definition inimitable. (Gill 1987, p. 330) The Fellowship came into existence because, to put it crudely, there was no other way for Wright to turn Taliesin into the grand country estate that he had always envisaged its being and because there was no other way for him to carry on the practice of architecture in the remote countryside, where draftsmen, secretarial help, and the like were hard to come by. The same reasons apply still more emphatically to Taliesin West, which at the time of its founding, in the late thirties, was even more difficult to get to than Taliesin North. (Gill 1987, p. 333)

Nothing in the Jensen/Wright orrespondence suggests that their hools served any purpose other 贲an the embodiment of their ideals, Gut one must look beyond the sentiminent of these utopian attempts to Ge realities of Jensen's and Wright's Aircumstances. Jensen also lived Targely, but not beyond his means or with flamboyance, and he suffered no ambition for The Clearing to become a "grand country estate." He was, nonetheless, hard-pressed for money and he needed assistants to manage his projects while he wrote and lectured. It is perhaps in this light that Jensen and Wright found the most beneficial mutual support: to each other, and to the world observing, their motives were pure of heart and mind, despite the realities they rarely acknowledged.

Wright kept his apprentices close in an almost cult-like isolation, with apprentices leaving the Fellow- ship only to promote the Broadacre City model or to attend the construction of other Wright projects. A few, like Paolo Soleri, left him to advance the premise of Organic Architecture on their own terms. Jensen referred some of his students and acquaintances to Wright's Fellowship, including Alice Drought's brother Jimmy, and Alfred Caldwell. Caldwell joined the Fellowship briefly in 1930. According to Jensen, in letters to Alice Drought:

I had a letter from Pittsburg [sic] this morning, from Caldwell. Two weeks was enough for him at Frank Lloyd Wright's. I had given him all summer, but I guessed wrong. (Jensen 1930c)

Really, I don't blame him for not sticking it out-I don't say that as disparaging to Mr. Wright at all, although there are some things I know that are better not committed on paper. (Jensen 1930d)

Because he worked for both Masters, and was apparently highly regarded by them, Caldwell's recollections are an important view of their influence on the people who came into their circles. ${ }^{14}$ When asked why he left Taliesin, Caldwell stated that there was no food or money for pay, the work of the apprentices was terrible, and he missed his wife, who had refused to live in the same house with Wright because of his reputation. He also stated that although he admired and respected Wright, he never went back to see him (Wolpert and Berndtson 1992).${ }^{15} \mathrm{He}$ sent Wright a letter two years after his departure, which describes a more thoughtful rationale for leaving Taliesin:
Dear Frank Lloyd Wright- May I come up to see you at Tal- iesin some time next month? My request is meager. I only wish to spend one day to talk to you a short time or as long as you are inclined. Silence is strong: I left Taliesin because you were greater than I supposed. I say this without ornament but it is in my heart. It is clean and true.

It is the gap that creates; a species of ignorance that creates. Let me have only a quick look at the giant. Let me observe only roughly the shape of his club. I shall go away to the next mountain and try my strength. I shall curse myself perhaps for not remembering in which hand he held his club. But my ignorance shall be my salvation. I shall end up by holding my club in my best hand-the hand most natural to me. Did Horace Trumbel write another Leaves of Grass?

So much for the incident of my leaving-

I must hold myself in. But listen oh cube maker, form-finder, trail-driver! I do not praise you half-measure. I do not first tip my hat to Louis Sullivan before I pay you a pretty compliment. I have calculated close and I know where you stand. I know your significance. Let Oswald Spengler go to Oak Park, to Tokio [sic] and California and then come back and write his book over again. (Caldwell 1932) ${ }^{16}$

Jensen did not keep his students close; he threw his students into local and regional conservation campaigns, which converted them into advocates for the native landscape. When they left Jensen, as he intended they should, he was not concerned if they called themselves landscape architects, only that they did not presume to undertake landscape design or artistry as he practiced it without first understanding their responsibility as advocates. In the Danish Folk School's value system, ". . . the prime outcome is personal growth and development in a collective environment," not a vocational, utilitarian certification (Leslie 1995). When a prospective student asked Jensen if he could guarantee that after study at The Clearing he would get a job, Jensen responded that after six months with him, he wouldn't think to ask such a question again (Eaton 1964, p. 219). Jensen's lengthy prospectus for The Clearing, revised and reprinted several times, clearly reiterated Folk School values with an emphasis on the development of the individual's appreciation of art, nature, and the American culture (Figure 7). 


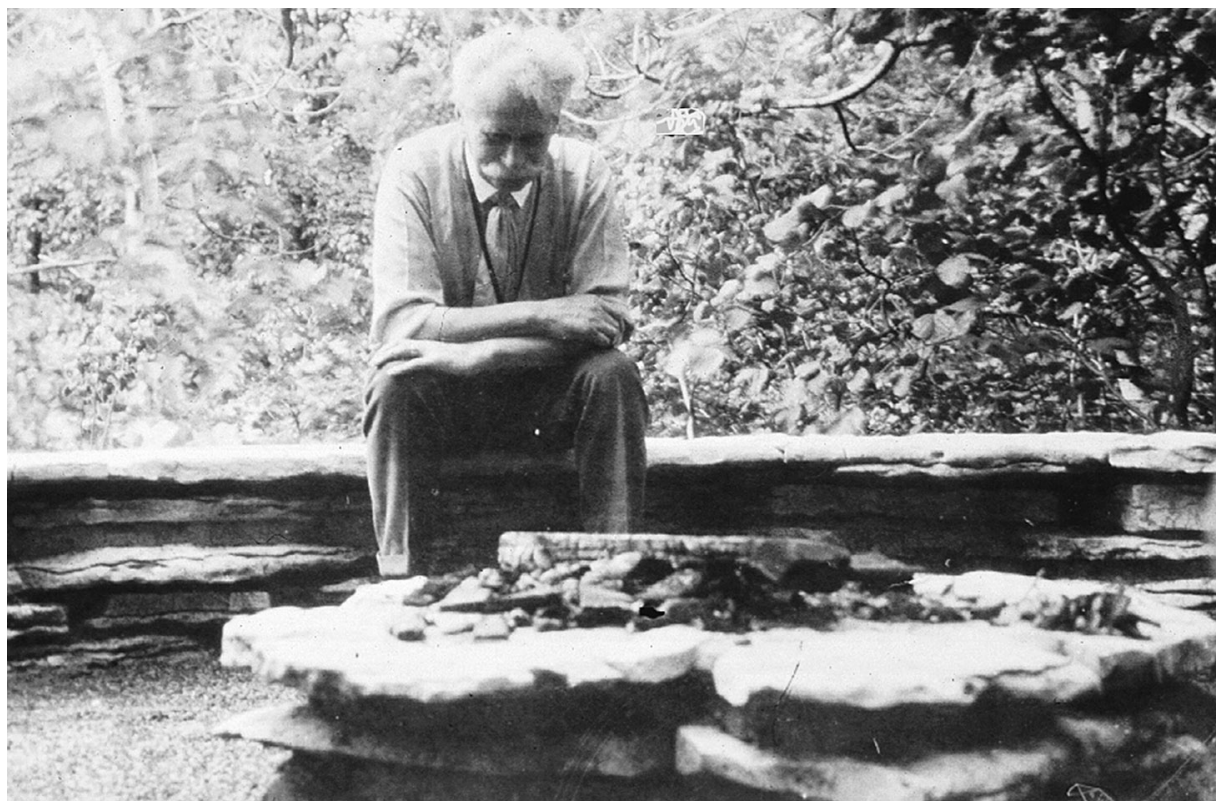

Figure 7. Jensen in one of the council rings at The Clearing, circa 1945. The council ring epitomizes Jensen's pedagogy: in a circle, no one sits at the head and all people are equal. Courtesy of The Clearing.

Jensen's education in Denmark was in the Danish Folk School tradition, advocated by the theologian, historian, poet, and nationalist Nicolai F.S. Grundtvig. This system emphasized communal living, cooperation, and the preservation of the Danish culture that was being oppressed by the Prussian presence of the 1830s. Students of the Folk School devised their own curricula and "learned to do by doing," ${ }^{17}$ depending not on books and professors of specialized expertise, but on det levende ord, "the living word" (Leslie 1995), an expression often used by Jensen when he wrote of The Clearing:

It is the living word that is the great intercourse between mankind-much more so than the written word, and whether this living word is spoken by the master of the art or whether by the student in the debates, it has lasting power. ${ }^{18}$

The goal of a Folk School education was not the pursuit of "abstract knowledge and of classical wisdom," focusing instead on the "immediate and the experiential," in order to reach a state of livoplysning, or "enlightenment for life" (Leslie 1995). When Jensen started The
Clearing, there were already a few folk schools in America that intended to deliberately reproduce the original Danish model, but Jensen believed the model should be adapted to an American spirit. $\mathrm{He}$ followed the basic routine of a Folk School's daily schedule, especially with the presentation of a "Thought for the Day" at breakfast, but he limited his curriculum to the study of nature, art, and the humanities in a general way, depending on visiting instructors like the Saarinens to expand his own teaching (Figure 8). ${ }^{19}$

Wright credited his inspiration for design and his pedagogy to the Japanese prints he collected, which he associated with his early childhood and his education in one of the country's first American versions of Froebel's kindergarten, and his mother was self-taught in Froebel's technique, as well (Pfeiffer 1987). Like the Folk Schools, the kindergartens focused on flexibility in the curriculum, with direction from women instructors using Froebel's Gifts, simple geometric objects de- rived from abstracted natural forms which could be manipulated to develop coordination, recognition, and creativity (Hughes 1900, p. 3). ${ }^{20}$

Froebel's system was based on the development of the child as early as possible to direct their development into citizens who would revere God and recognize Him in nature, hence the term kindergarten, "children in" or "children from the garden." Wright's enrollment frequently included college graduates and people with mature experience of the world; nonetheless, their apprenticeship began with derivations of Froebel's approach to child development, learning to manipulate and draft the "cosmic, geometric elements" (Pfeiffer 1987) as the underlying foundation of Organic Architecture, eventually advancing to the manipulation of the materials found in nature.

Had it not been for his suspicion of all things German (Eaton 1964, p. 8), ${ }^{21}$ Jensen might have admitted that much of Froebel's philosophy complemented that of the Danish Folk School. Froebel's doctrine applied to Jensen's pedagogy as well as his design philosophy, in particular the doctrine of "correspondences, or the analogy everywhere subsisting between spirit and body," the scheme of resultant "connections which run throughout the world," and the doctrine of Gliedganzes or "memberwhole, that the whole world works in each part," that the "character of the organized whole depends on the development of its individual elements" (Kilpatrick 1916, p. 16). Jensen may never have studied Froebel or his techniques, but Grundtvig is one of many authors to whom Wright gives credit in his autobiography, and Froebel is not listed (Gill 1987, p. 324).

\section{War and Resignation}

As both The Clearing and Taliesin grew and became established, in both their facilities and their enrollments, the friendship of Wright and Jensen was strained by their busy lives and ultimately by Jensen's belief that Wright's avid collection of Japanese artifacts and prints gave an oriental aura to the American spirit of 




Figure 8. Jensen outside the Schoolhouse at the Clearing, circa 1945. The foreground garden was the quarry for the building's stone. Two Chicago architects, Hugh Garden and John S. Van Bergen (who once worked for Wright) advised Jensen in the design of the Schoolhouse. Courtesy of The Clearing.
Wright's designs. Jensen was quite vocal in his opinion of the Japanese and their manipulation of Nature, and in a 1937 letter to a German editor he wrote:

Frank Lloyd Wright is a dear friend of mine, and a great architect, but oriental, and here we part. When the last Anglo Saxon has gone to his forefathers, the soul of Frank Lloyd Wright will halloo over his grave. (Eaton 1964, p. 149)

In the early 1940s, with the country at war, Wright's longstanding disgust with the classical model of memorial architecture in Washington, D.C. and his concern for the resolution of the American conflict with two cultures he revered, the German and the Japanese, prompted him to distribute the Broadacre City Petition. ${ }^{22}$ The petition asked the American government to endorse and support Wright's development of the Broadacre City Model:

We, the undersigned, respectfully ask that the Administration of our Government authorize Frank Lloyd Wright to continue the search for Democratic FORM as the basis for a true capitalistic society now known as Broadacre City. We believe that work should immediately be declared a worthy national objective and the necessary ways and means freely granted him to make such plans, models, and drawings as will enable our citizens and other peoples to comprehend the basic ideas the plans, models, and drawings represent and which without political bias or influences will be invaluable to our people when peace is being considered. (Gill 1987, p. 416)

The petition was mailed to the White House with hundreds of signatures; Buckminster Fuller's, John Dewey's, Georgia O'Keefe's, Albert Einstein's and many other notable signatures appeared on the petition, but Jensen's did not. According to Mertha Fulkerson (1970), when Jensen received his copy of the Petition, he wrote, "Go to Hell" on it and mailed it back to Wright, ${ }^{23}$ a gesture that marked the end of their friendship, but not their correspondence.

Like many legends, this dramatic story persists in the Jensen lore 
as evidence of the end of Jensen's friendship with Wright. What Fulkerson failed to mention was that Jensen wrote a brief letter in response to the petition. On February 12, 1943 she typed Jensen's second-to-last letter to Wright:

Dear Frank: My viewpoint of life and its intellectual functioning will not permit me to sign your petition. In minor things we can agree, but there are supreme qualities in the long chain of human endeavor where we completely disagree. Years of close contact with the soil have guided my viewpoint in what constitutes our real and true purpose on this earth.

To explain my views in detail can further nothing, as at your age, your goal is set, so all I can say is good luck.

Kindest regards, Jens Jensen (Jensen 1943a)

Like the pot calling the kettle black, Wright's response to Jensen takes a bitter tone:

Dear Jens, You dear old Prima Donna-I don't know whether you exaggerate your own sense of yourself or exaggerate my sense of myself. It doesn't much matter either way. But I think you would be interested to see how a minority report, such as I might bring in with my experience in the study of structural Form as interpretation of nature, would compare with yours, you who imitate nature.

Yes, our points of view diverge. But that wouldn't prevent me from helping you get a job you wanted to do. You are a realistic landscapist. I am an abstractionist seeking the pattern behind the realism - the interior structure instead of the comparatively superficial exterior effects you delight in. In other words I am a builder. You are an effectivist using nature's objects to make your effects.

The matter is unimportant except that I should think a man like you who has lived as long as you have (in times past cribbing some of my "patterns" to decorate your pictures) would be curious to see what the other fellow's viewpoint could reach. I find that I can be interested in that with which I supremely disagree, and I continually learn from my opposites.
This is not to ask you to sign my appeal for a job to help make the world a better world to live in but to sympathize with a man to whom age has not brought tolerance and vision but instead animus and opinion-which he values above discovery and friendship. (Wright 1943)

One might wonder, if Albert Einstein had refused to sign the petition, would he have received a letter which insulted his character, his age, his work, and claimed that the theory of relativity was a copy of Wright's "patterns?" As best can be determined, Jens Jensen had the last word in March of 1943, at least in writing:

\section{Dear Frank}

I did not think I could ever get you to write me a letter. But here it is! Thanks for the compliments. You are still the same Frank, although I fear a little less poetic. (Jensen 1943b)

Jensen's fundamental rejection of the Broadacre City Model as the democratic ideal may have been founded in his belief that "the car has done much to destroy the finer feelings in man, and in the tomorrow it will have to keep its place," ${ }^{4}$ a sentiment which is ironic, given Jensen's relationship with Henry Ford as client and benefactor, but squarely in opposition to the futuristic accommodations of the automobile in the Broadacre City plans. Or the rejection may have been the result of a lifelong abhorrence for militaristic, dictated planning, an impression made on Jensen when he was forced to serve in the Prussian Imperial Guard. The Broadacre City Model, if it had been adopted, would have discouraged more original or individualized plans from subsequent designers and citizens. These beliefs and the Danish jantelov may have combined in the ultimate rejection, but in any case, Jensen's refusal to sign the petition marked the end of his support for Wright and his resignation from their friendship. Although they may have continued to communicate in some other way, the letters ended with this exchange, if the meticulous records of the Frank Lloyd Wright Foundation are any indication. By this time the 83-year-old landscape artist might have felt it was time to stop holding the hand of a 76-year-old architect. Frank Lloyd Wright surely felt the silence of one of his most steadfast and tolerant friends, Jens Jensen.

\section{Acknowledgements}

Early portions of this work were presented at The Clearing Institute, CELA 1997, and CELA/ASLA 1999. The author is grateful to the gracious staff of the Frank Lloyd Wright Foundation, specifically Margo Stipe, Indira Berndtson, Bruce Brooks Pfeiffer, and Geronimo. The author thanks Michael Stieber and Carol Doty (formerly) of Morton Arboretum, and the staff of The Clearing. The author owes much to her Clearing buddies and generous critics Gene DeTurk, Bill Tishler, and Bob Grese for many years of support and inspiration, and she wishes to thank two out of three anonymous reviewers who thoughtfully raised the bar (instructions included, some assembly required).

\section{Notes}

1. The author presumes from Fulkerson's book The Story of The Clearing and from the legends of the place that Fulkerson did not approve of Wright or his lifestyle, and she may have been reluctant to contribute to their relationship by typing letters to him, or perhaps knowing her opinion, Jensen spared her the chore or himself the asking of it.

2. Purtell, Josephine. "Dean of Landscape Artists at 83 Looking to Future," Milwaukee Journal, September 9, 1943.

3. Fulkerson and Corson 1972, p. 15: "To the studio in Ravinia came such notables as the Swedish sculptor Carl Milles, Sherwood Anderson, Eliel Saarinen, Vachel Lindsay, Frank Lloyd Wright, Louis Sullivan, the dancer Sybil Shearer, and singers, players, musicians, composers, and other thinkers and doers drawn to the group that gathered there."

4. Eaton 1964, pp. 220-222, describes the Marquette projects (1936) which may have resulted in an agreement, tacit or otherwise, that Wright and Jensen would not collaborate in such work again. Grese 1992, pp. 47-48, pp. 200-217 lists the Jensen/Wright collaborations.

5. Gill 1987, pp. 289-301, describes the desperate period of 1924-1928, when Wright's troubles included the imminent foreclosure on Taliesin for a debt of $\$ 43,000$, and the 
forced sale of his Japanese prints at auction in New York City. In 1927, a handful of friends, including Mrs. Avery Coonley, formed Frank Lloyd Wright, Incorporated to collect and manage Wright's commissions, and gradually discharge Wright's debts and give him an allowance. In May 1928, this corporation bought Taliesin at auction when Wright's commissions could not cover the debts.

6. Spirn, Ann Whiston, "Frank Lloyd Wright: Architect of Landscape," in DeLong 1996. This reference is found in the endnotes of Spirn's chapter, p. 168.

7. See Grese 1992, pp. 120-136 for an overview of Jensen's conservation efforts and his contributions to the founding of The Friends of Our Native Landscape and the Prairie Club.

8. Eaton 1964, p. 211. Eaton uses the name "Taliesin West" when describing this 1934 trip. However, Pfeiffer and others mention the Arizona property was not purchased until 1936 , with construction of the permanent buildings beginning in 1938, near the temporary camp Jensen visited. In 1913, the Chicago City Club, when Jensen was their Chair of City Planning, held a competition for the design of a suburban community, and Wright did not enter his Design, which evolved into the Broadacre City, m the competition, instead choosing to submit 造e scheme "hors concours," as one reviewer Dot it, or "outside the competition." Jensen 夏s on the jury for the competition, and it Would be a dispute over Broadacre City that ultimately ended their friendship thirty years Qiter. For more about Wright's tireless efforts t promote Broadacre City and its context in Meory and city planning of the early twentieth entury, see Yeomans 1916. See also Arnold E71, pp. 84-86 and Scott 1971, pp. 336-337. Jensen's correspondence of the winter and spring of 1938 (Morton Arboretum), the pesod when his Schoolhouse was being built, in逆udes letters similar to Stern's and the confirmation of tax-exempt status by Jensen's attorney. The Clearing is currently a not-forfrofit corporation under Section 501 (c) (3) of He Internal Revenue Code.

7). Letter from Frederic Sammond, attorney For the Frank Lloyd Wright Foundation, to AsSemblyman Warren Grady, Chair of the TaxaGon Committee, dated May 9, 1955. Sammond ansuccessfully argued the Foundation's case at fe Wisconsin Supreme Court in 1954, and wrote this letter in support of Bill 328A, which would have altered the original legislation regarding exemption, if it had passed. Other letters regarding this failed legislation appear in the same time period of the collection, Frank Lloyd Wright Foundation.

11. Jensen formed his Board to do the fundraising and financial chores for him, leaving him with time to write, to lecture all over the country, and to work with his students on the experimental, experiential grounds of The Clearing. He rarely had money to spare, but when he could he bought acreage adjoining The Clearing, eventually accumulating about 128 acres. Wright may have forfeited nonprofit status to protect his vision and control, but Jensen's distaste for control certainly cost him his vision. Although financial management and fundraising were the original duties of Jensen's Board, since his death it has elected not to buy adjoining or nearby properties when they were available, in order to expand the programs needed to generate revenues. Instead, the Board has developed The Clearing's grounds, first with two vacation rental units, and most recently with an office building, named the Jens Jensen Visitor's Center, to receive the tourists Jensen despised. The Clearing's Bylaws (Article I, Section 2, pp. 1-2, April 1987) state: "The land owned and used by the school must be kept so far as possible in its present state. The portion which is forest must remain forest and the portion which is clearings of open fields must be left as such. The forest must be left free from man's intervention ... If in the future the directors consider it desirable for the school to increase its cultivated areas, this must be done by the acquisition of additional land."

12. "The Frank Lloyd Wright Foundation," brochure distributed at Taliesin, Spring Green, Wisconsin, September 1992.

13. Jensen and Wright's earliest brochures listed sums of about $\$ 1,000$ per year for tuition, and in the 1930s it must have been difficult to realize a steady income from this money for either school. The few financial records available do not make clear any collection of tuition. When Wright began the Fellowship, there were over twenty apprentices enrolled, which would have been over $\$ 20,000$ in tuition income. Given Wright's circumstances, and similarly Jensen's, it is clear they did not have this amount of money, although what little they could collect would have been needed.

14. See Domer 1997, pp. 10-13. According to Caldwell (p. 10), Jensen and Wright were not friends. It is the fundamental premise of this paper that they were.

15. Domer 1997, p. 13 relates that Caldwell did in fact see Wright again, between 1934 and

1936

16. The reference to Oswald Spengler comes from Spengler's exhaustive text, The Decline of the West, first published in 1926, wherein he includes American architecture of the nineteenth and twentieth centuries under the heading of "Winter" and "Decline," and refers to the "Transformation of Music, architecture, and painting into mere craft-arts," overleaf table, p. 428.

17. "Learning by doing" is the phrase used by Jensen in the various brochures for The Clearing. To "learn to do by doing" is the phrase used by Froebel in his "Educational Laws," quoted in Froebel's Laws for All Teachers, by James L. Hughes, Appleton and Company, NY 1900 .

18. From one of the earliest drafts of Jensen's prospectus for The Clearing, entitled "School of Landscape Architecture:"Jensen Collection of the Morton Arboretum, Lisle, Illinois, n.d., p. 2. Variations of this draft statement appear in the printed editions.

19. See Eaton 1964, p. 217. Jensen's friendship with the Saarinens began soon after they immigrated. Jensen had been training a young ap- prentice in his office to be his manager at The Clearing. Mertha Fulkerson's role was supposed to be that of weaving instructor, not manager (as she said in 1970, "he didn't want a skirt") so Jensen sent her to the Saarinens at Cranbrook for weaving classes. The apprentice died, and Jensen did not recruit another to replace him. Management (and cooking, plumbing, housekeeping, etc.) fell to Fulkerson by default. Because of her devotion to Jensen and his ideals, and because of her diligence to keep the place open, The Clearing is still a school, with weeklong classes from June to October in nature, art, and the humanities. 20. See also Wiggin and Smith, 1897, pp. 189192.

21. See also see Egan and Tishler 1999, pp. 1129 for an understanding of Jensen and his position on Germany.

22. Eaton 1964, p. 222 gives another dimension to the story: “. . . Wright sought Jensen's aid in his effort to be appointed architect-inchief for the State Department's building program. Though Jensen still admired Wright's architectural talents enormously, he did not believe that his selection would be good public policy and therefore refused his support." 23. This particular piece of correspondence is not in the Frank Lloyd Wright Foundation's collection of letters from Jensen to Wright. 24. Jensen 1990, p. 92. In A Greater West Park System, (1920, p. 20), Jensen states, "A better architectural and livable city cannot be brought about by grand plans that are instigated from above and thrust upon the people from without; it must come from within and must grow out of the soul of the people themselves." For more on Jensen's ideal of the city, see Egan and Tishler and their excellent overview of writing by and about Jensen, pp. 11-12.

\section{References}

Arnold, Joseph L. 1971. The New Deal in the Suburbs: A History of the Greenbelt Town Program 1935-1954. Columbus: The Ohio State University Press.

Aust, Franz. 1929. Letter to Wright. December 17. Frank Lloyd Wright Foundation

Caldwell, Alfred. 1932. Letter to Wright. March 27. Frank Lloyd Wright Foundation.

Doeserich, Emma, et al. 1941. Outdoors with the Prairie Club. Chicago: Paquin Publishers.

Domer, Dennis, ed. 1997. Alfred Caldwell: The Life and Work of a Prairie School Landscape Architect. Baltimore: Johns Hopkins University Press.

Eaton, Leonard K. 1964. Landscape Artist in America: The Life and Work of Jens Jensen. Chicago: University of Chicago Press.

Egan, Dave, and William H. Tishler. 1999. "Jens Jensen, Native Plants, and the Concept of Nordic Superiority," Landscape Journal 18(1): 11-29.

Fulkerson, Mertha and Ada Corson. 1972. The Story of The Clearing: A Door County Legend. Chicago: Roach House Press. 
Fulkerson, Mertha. 1970. Interview at the Clearing with Darrel Morrison and others. Notes taken by Professor Eugene DeTurk, Purdue University, May 14, 1970.

Gill, Brendan. 1987. Many Masks: A Life of Frank Lloyd Wright. New York: Ballantine Books.

Grese, Robert E. 1992. Jens Jensen: Maker of Natural Parks and Gardens. Baltimore: Johns Hopkins University Press.

Henning, Randolph C. 1992. At Taliesin: Newspaper Columns by Frank Lloyd Wright and the Taliesin Fellowship 1934-1937. Carbondale and Edwardsville: Southern Illinois University Press.

Hughes, James L. 1900. Froebel's Laws for All Teachers. New York: Appleton and Company.

Jensen, Jens. 1920. A Greater West Park System. Chicago: West Chicago Park Commissioners.

. 1927. Letter to Wright. November 22. Frank Lloyd Wright Foundation. 1929. Letter to Wright. January 3. Frank Lloyd Wright Foundation. . 1930a. Letter to Wright. November 28. Frank Lloyd Wright Foundation. . 1930b. Letter to Drought. July 1. Jensen Collection, Morton Arboretum. . 1930c. Letter to Drought. April 7. Jensen Collection, Morton Arboretum. . 1930d. Letter to Drought. April 21. Jensen Collection, Morton Arboretum. 1943a. Letter to Wright. February 12. Frank Lloyd Wright Foundation. 1943b. Letter to Wright. March 8. Frank Lloyd Wright Foundation. 1990. Siftings. Baltimore: Johns Hopkins University Press. Reprint of 1939 edition by Ralph Fletcher Seymour, Chicago.

Kilpatrick, William H. 1916. Froebel's Kindergarten Principles Critically Examined. New York: The MacMillan Company.

Leslie, David W. 1995. "Radical Humanism in Practice: The Scandinavian Folkehojskoler," reprinted from The Review of Higher Education in Option: Journal of the Folk Education Association of America, 18(2).

Meehan, Patrick J. 1984. The Master Architect: Conversations with Frank Lloyd Wright. New York: Wiley-Interscience Publication.

Pfeiffer, Bruce Brooks. 1982. Frank Lloyd Wright: Letters to Apprentices. Fresno: The Press at California State University. 1987. Frank Lloyd Wright: His Living Voice (audiotape). Fresno: The Press at California State University.

Sammond, Frederic. 1955. Letter to Assemblyman Warren Grady, Chair of the Taxation Committee. May 9. Frank Lloyd Wright Foundation.

Scott, Mel. 1971. American City Planning Since 1890. University of California Press.
Spengler, Oswald. 1932. The Decline of the West. New York: Alfred A. Knopf, Inc.

Spirn, Ann Whiston. "Frank Lloyd Wright: Architect of Landscape," in DeLong, David G., ed. 1996. Frank Lloyd Wright: Designs for an American Landscape 19221932. New York: Harry N. Abrams, Inc.

Stern, Marion. 1938. Letter to Jensen. May 25. Jensen Collection, Morton Arboretum.

Wiggins and Smith. 1897. Froebel's Gifts [Volume 1 of 3 of The Republic of Childhood]. Cambridge: Houghton and Mifflin Company.

Wolpert, Gloria, and Indira Berndtson. 1992. Interview of Alfred Caldwell, January 31, for the Frank Lloyd Wright Oral History Project. Frank Lloyd Wright Foundation.

Wright, Frank Lloyd. 1927. Letter to Jensen. November 12. Frank Lloyd Wright Foundation. 1928. Letter to Jensen. December 8. Frank Lloyd Wright Foundation. . 1929. Letter to Aust. December 16. Frank Lloyd Wright Foundation. 1930. Letter to Jensen. November 3. Frank Lloyd Wright Foundation. 1943. Letter to Jensen. March 1. Frank Lloyd Wright Foundation.

Yeomans, Alfred B., ed. 1916. City Residential Land Development: Studies in Planning, Competitive Plans for Subdividing a Typical Quarter Section of Land in the Outskirts of Chicago. Chicago: The University of Chicago Press. 